\title{
Theoretical and experimental investigation of plasma dynamics for laser- induced machining mechanism
}

\section{Lazer destekli imalatta plazma dinamiklerinin teorik ve deneysel olarak araștırılması}

\author{
Serap ÇELEN ${ }^{*}$ \\ 1Department of Mechanical Engineering, Faculty of Engineering, Ege University, Izmir, Turkey. \\ serap.celen@ege.edu.tr
}

Received/Geliş Tarihi: 10.11.2016, Accepted/Kabul Tarihi: 02.02.2017

* Corresponding author/Yazıșılan Yazar

doi: $10.5505 /$ pajes.2017.94758 Special Issue Article/Özel Sayı Makalesi

\section{Abstract}

The quality of laser micro-machining process (micro welding, drilling, surface structuring etc...) has vital importance for electronic, aviationaerospace and biomedical industries. Dynamics of laser-induced plasma are determined with some parameters such as laser intensity, beam waist diameter and ambient gas conditions. When the plasma density is limited with a threshold value, the laser energy can not transmitted to the material due to the rarefied plasma. This decoupling threshold has a crucial role for micro-machining operation. In the scope of this paper, the behaviour of the plasma dynamics has been examined both theoretically and experimentally for titanium material and optimal laser intensity threshold was reported to prevent dissipation of beneficial process energy and to compare numerical investigations.

Keywords: Laser-induced detonation waves, Plasma physics, Micro machining

\section{Introduction}

Although Society of Precision Engineering was established eighty-three years ago in Japan, the journal of Precision Engineering was first published in 1979 [1]. In fact, manufacturing of miniaturised systems were proposed by Richard Feynman [2]. American Society of Precision Engineering was formed in 1986. Precision engineering formed a big umbrella for metrology, calibration, error compensation, controls, design methodology, uncertainty analysis, actuators and sensors design and ultra-precision machining topics [3].

Today laser may be considered as an excellent tool for high precision material processing due to its unique properties [4]. Although ultrasecond lasers have been developed, nanosecond lasers which have intermediate pulse durations are still dominant in micro-machining industry due to their low costs. Micro production with using these systems enables more reliable manufacturing than other systems.

Laser-material interaction mechanisms were classified according to laser intensity and plasma physics had an important role in pulsed micro-machining [4],[5]. Laser surface modification with close infrared wavelength field is influenced by heat [6]. So temperature cycle of the material surface is the most crucial factor for nanosecond laser micromachining, there is only one important question at this point. How we can govern effective laser intensity and what is the main process parameter? Understanding of "plasma
Öz

Lazer destekli mikro-imalat (mikro kaynak, delme, yüzey yapılandırma $v b . .$.$) prosesinin kalitesi elektronik, havacılı- uzay ve biyomedikal$ endüstrileri için özel bir öneme sahiptir. Lazerin olușturduğu plazmanın dinamikleri lazer güç yoğunluğu, ışın odak çapı ve çevre koșulları tarafından belirlenmektedir. Plazma yoğunluğunda eșik değerine ulaşıldığında plazma korumasına bağlı ışınım kayıpları sebebiyle, lazer enerjisi malzemeye aktarılamamaktadır. Bu ayrıșma eșiği mikro-imalat operasyonu için kritik bir role sahiptir. Bu makale kapsamında, titanyum malzeme için plazma dinamikleri teorik ve deneysel olarak incelenmiș ve faydalı prosess enerjisinin kaybını önlemek için optimum lazer yoğunluk eşiği rapor edilmiş ve numerik çalışmalarla karşılaştırılmıştır.

Anahtar kelimeler: Lazerden kaynaklanan patlama dalgaları, plazma fiziği, mikro imalat

dynamics" can be a driving force to describe related physical events accurately and "plasma threshold intensity" is the most important parameter. Photons interact with the atoms of the target material and this situation leads plasma formation due to highly charged atoms and electrons in laser micromanufacturing. Plasma is the highly ionized vapour and the state of matter such as solid, liquid and gas. When the plasma is formed, the magnitude of the heat fluxes increased dramatically due to the higher absorption of the laser energy [7]. Micro-nanodevice production requires the description of hydrodynamic behaviours of plasma flows. Because accurate calculations of microscale flow characteristics have imperative role [8]. Also the temperature, recoil pressure, vapour expulsion rate, liquid expulsion rate are important factors to control process parameters [9].

Hirschfelder et al. reported theoretical behaviours of gas and liquids in 1954 [10]. It was emphasized that there was a term congestion in laser-induced machining such as vaporization, desorption, ablation, decomposition [11]. For this reason some laser terms such as laser-induced splashing were used to describe pulsed laser material interaction [12]-[16]. In the background literature, several researchers focused on the evaporation dynamics of laser irradiated metal specimens from 1967 [17]. Anisimov and Anisimov et al. reported kinetics of vaporization for low power laser interaction [18],[19]. Olstad and Olander investigated pulsed laser interaction for different material surfaces [20],[21]. Mathematical description of laser-induced energy transport concept was reported by Andrews and Attey in 1975 and 1976 
[22],[23]. Allmen developed a theoretical model for laser drilling process in 1976 [24]. Knight investigated rapid vaporization concept in 1979 . He approached to the concept with a different perspective from background studies with using sonic flow calculations [25]. Chan and Mazumder reported a laser vaporization model with using Mott-SmithApproach in 1987 [26]. After 1988, second stage investigations were conducted for dynamic modelling of laser machining with using analytical and applied methods for different purposes. Kelly and Dreyfus emphasized some difficulties due to high time-of-flight temperatures in laserinduced vaporization [27]. They reported that surface temperature might be lower than the estimated value and when the collisions were insufficient, an unsteady-adiabatic expansion process occurred just like a strong barrel which was fired from a finite charge [11],[27],[28]. Singh et al. developed a theoretical model for nanosecond laser-induced plasmas [29]. Aden et al. investigated laser-induced vaporisation of two metallic specimens such as aluminium and iron and they proposed a theoretical model with using Euler equations. They reported pressure values for a $10^{11} \mathrm{~W} / \mathrm{m}^{2}$ laser intensity with an Nd:YAG laser irradiation [30],[31]. Chen et al. reported hydrodynamic modelling of laser-induced expansion of the target materials and the variation of the surface pressure with interaction time via Saha equation [32]. Capewell and Goodwin used Direct solution Monte Carlo (DSMC) model for calculating fluid-flow characteristics of gases in micro-scale [33]. Also there were another studies for high intensity laser ablation [34]-[36]. Background studies and publications show that the major focus has been made on the development of vaporization models for the laser ablation [37]; however, there is a lack of knowledge for understanding plasma mechanism and its process dynamics. Therefore, it would seem reasonable to state that further promising studies are needed to enhance the production quality. The importance of the "plasma threshold intensity" was emphasized for laser micro-machining operation. Also within the scope of this investigation, effect of laser-induced recoil pressure was illustrated and the optimal laser intensity threshold was reported to obtain beneficial plasma effects with using a 20 Watt ytterbium fiber laser.

\section{Material and method}

\subsection{Theoretical plasma physics in manufacturing science}

Plasma has been an active research area in manufacturing engineering. Although plasma may be a beneficial tool for general manufacturing technologies such as plasma welding, plasma-aided coating where it facilitates the energy flow, it may prevent transmitted laser energy and thus it may deteriorate the quality of the process for laser manufacturing applications [4]. Figure $1 \mathrm{~b}$ represents the negative effect of the plasma.

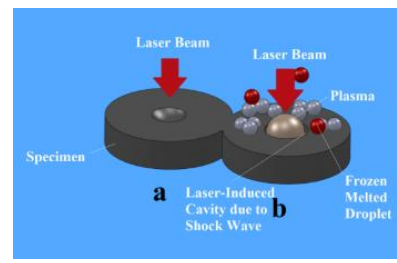

Figure 1: a) Laser-Induced Evaporation, b) The negative effect of laser-induced plasma [16]
In the background investigations, hot surface temperature was calculated with using Eq.1 [9]. Where $\mathrm{T}_{0}, \mathrm{I}_{a}{ }^{\prime}, \rho, \kappa$ and $\xi$ refer ambient temperature, absorbed laser intensity, density, thermal diffusivity, the coordinate point respectively, $c_{p}$ represents specific heat and $u_{d}$ is the laser processing speed [9]. However, there are some difficulties to estimate absorbed laser intensity and laser processing speed accurately with iterations for numerical calculations.

$$
\mathrm{T}_{\mathrm{h}}=\mathrm{T}_{0}+\frac{\mathrm{I}_{\mathrm{a}}{ }^{\prime}}{\rho \mathrm{c}_{\mathrm{p}} \mathrm{u}_{\mathrm{d}}} \exp \left(-\frac{\xi \mathrm{u}_{\mathrm{d}}}{\kappa}\right)
$$

Then recoil pressure calculation was proposed by Anisimov with using Eq.2 [18],[19]. Where $\mathrm{L}_{v}, \mathrm{~m}_{\mathrm{v}}, \mathrm{A}$, T refer vaporization enthalpy, mass of the vapour molecule, area and surface temperature respectively. They used $\mathrm{Q}_{0}$ and $\mathrm{S}$ symbols to describe laser power and interaction area in their equation [7],[18],[19]. However, assumption of low laser power density was used in this method thus plasma shielding effect was neglected. Eq. 3 represents another formula for the estimation of the recoil pressure where $L_{p}$ refers heat of vaporization for a particle [9].

$$
\begin{gathered}
\mathrm{P}_{\mathrm{s}}=\left[\frac{1.69 * \mathrm{I}_{\mathrm{a}}}{\mathrm{A} * \sqrt{\mathrm{L}_{\mathrm{V}}}}\right]\left[\frac{\sqrt{\left(\mathrm{k}_{\mathrm{B}} * \mathrm{~T}\right) /\left(\mathrm{m}_{\mathrm{V}} * \mathrm{~L}_{\mathrm{V}}\right)}}{1+2.2 *\left(\mathrm{k}_{\mathrm{B}} * \mathrm{~T}\right) /\left(\mathrm{m}_{\mathrm{V}} * \mathrm{~L}_{\mathrm{V}}\right)}\right] \\
\mathrm{P}_{\mathrm{S}}=\mathrm{P}_{0} \exp \left[\frac{\mathrm{L}_{\mathrm{p}}}{\mathrm{k}_{\mathrm{B}} \mathrm{T}_{\mathrm{v}}}\left(1-\frac{\mathrm{T}_{\mathrm{V}}}{\mathrm{T}_{\mathrm{h}(\text { old })}}\right)\right.
\end{gathered}
$$

Today many laser material processing applications have been conducting laser intensity ranges in between 100-1000 $\mathrm{MW} / \mathrm{cm}^{2}$ and higher values thus the effect of plasma must be considered [38]. For this reason mathematical models of hot surface temperature and recoil pressure should be updated. Plasma dynamics and its equations have a key role in laser micro-machining, where the laser intensity is a determinant factor. The last model was developed in 2016 [16]. In the scope of this investigation, a different recoil pressure calculation was proposed with updating a novel hot surface (remodified Clausius-Clapeyron with a correction factor) approach [16] and the accuracy of the method was confirmed with experimental tests (Eq. 4).

$$
\mathrm{P}_{\mathrm{S}}{ }^{\prime}=\mathrm{P}_{0} \exp \left[\frac{\mathrm{L}_{\mathrm{p}}}{\mathrm{k}_{\mathrm{B}} \mathrm{T}_{\mathrm{v}}}\left(1-\frac{\mathrm{T}_{\mathrm{v}}}{\mathrm{T}_{\mathrm{h}(\text { Çelen, 2016) }}{ }^{\prime}}\right) * \mathrm{C}_{\mathrm{F}}\right.
$$

Material properties were given in Table 1. Details of the experimental set-up were given in the following section and obtained results were illustrated in the Results and Discussion Section.

Table 1: Physical properties of titanium used in numerical analysis.

\subsection{Material and experimental details}

ASTM B265 grade 2 commercial pure titanium material was used to observe the effect of laser-induced detonation waves due to plasma formation. Surfaces of specimens were grinded, polished and cleaned by ethanol solution before the experimental tests. They were conducted with a 20 Watt Ytterbium Fiber Laser source $(\lambda=1060 \mathrm{~nm})$ with a precise motion control system in air at atmospheric pressure. Specimens were micro-machined with using rastering mode. Pulses were adjusted to Q-switched TEM00 mode to obtain 
maximum laser intensity normal to the titanium target surface which corresponds to the center of the beam. F-theta $f=160$ mm lens was used to obtain minimum focus.

\section{Results and discussion}

Nanosecond pulse generates explosive phase-change, strong shock waves, plasma formation [7]. In the literature, it was reported that laser supported detonation waves (LSDWs) occurred at effective laser intensity range between 100-1000 $\mathrm{MW} / \mathrm{cm}^{2}$ and upper for some investigations [38]. The threshold laser intensity value was estimated about 1425 $\mathrm{MW} / \mathrm{cm}^{2}$. Also results of this study were found consistent with former studies for pulsed laser operations [30],[31] and [38][40].

Recoil pressure increased with effective peak power density [16]. (Figure 2) The first laser power led to the significant vaporization and ionization of the material. (Figure 2a) Effective energy transfer occurred due to the plasma coupling [7]. When it was increased, immediate expansion of the plasma formed and melted droplets were scattered due to laser induced-detonation waves. Increment of the surface pressure can be seen from the graph and also its proof was given in Figure 2b. The effect of strong deflagration front of the shock wave was given at Fig 2c. Laser beam caused a tear effect on the material instead of the evaporation where the machining process was not possible [16]. (Figure 2c) High energy supply to the surface was broken and it prevented overall ionization. It may be interpreted that the increased laser density caused decoupled plasma and laser energy did not reach to the surface effectively to vaporize the material [16]. It was reported that the material transition took place from purely elastic state to elastic-plastic state due to the laser-induced shocks and material losses much of its shear strength [41]. For I $\leq$ Ip normal vaporization and effective ionization was observed. However, for I $\geq$ Ip the system was metastable and machining was difficult due to the intermittent characteristics of the laser energy [16].

Aden et al. reported surface pressure graphics for laser irradiation. When the effect of their relatively long pulse durations was assumed, results of this study were found consistent with their pressure values [30],[31]. Bergel'son et al. emphasized that "the stable regime occurred at 2500 $\mathrm{MW} / \mathrm{cm}^{2}$ when $65 \mathrm{~ns}$ pulse duration" was used [39]. McKay et al. reported that "the transition from laser-induced detonation to laser-induced radiation took place at $46 \mathrm{~ns}$ pulse duration with using 1,06 $\mu \mathrm{m}$ laser wavelength" [40]. Also a comprehensive report which included transition regions for laser-induced waves was published [38]. In this study, experiments were conducted with relatively longer nanosecond pulse durations and intermediate laser intensity levels, thus laser-induced detonation effects were seen on surfaces of specimens and laser-induced radiation was not observed.

There are some process parameters for plasma occurrence such as laser intensity, material composition, ambient gas properties and laser wavelength [38]. The most crucial parameter is "the effective laser intensity" which determines the surface temperature of the target. Plasma threshold should be a strong indicator for material processing [38]. At this stage, this novel approach must serve some purposes such as precision control of the laser-material interaction with understanding the plasma dynamics of the operation. Also their precise control will lead a higher quality machining operation.

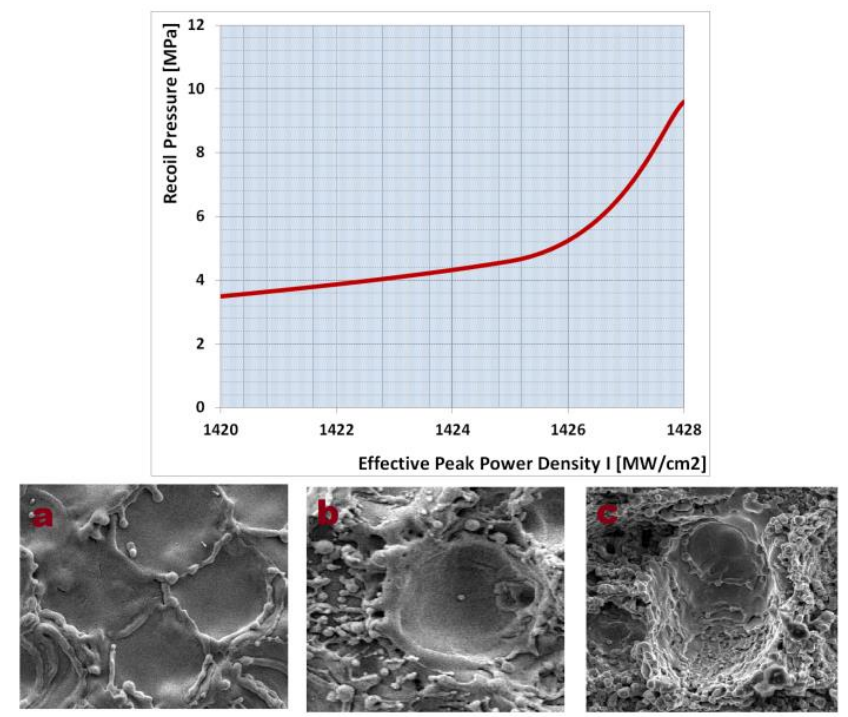

Figure 2: Recoil pressure variation with effective peak power density [16].

\section{Conclusion}

Plasma dynamics were investigated and physical insights and the current limits were discussed.

Mathematical analysis was performed to obtain recoil pressure values. Plasma threshold intensity was proposed about $1425 \mathrm{MW} / \mathrm{cm}^{2}$ and unfavorable shockwave period was started after this value. Shockwave behaviour of the metal vapour was examined experimentally and related micrographs were given. They proved numerical approach of this study for plasma dynamics.

\section{Acknowledgement}

The author expresses her sincere thanks to ICON Machinery.

\section{References}

[1] Mahalik NP. Micromanufacturing and Nanotechnology. Berlin-Heidelberg, Germany, Springer Verlag, 2006.

[2] Feynman RP. "There is plenty of room at the bottom". Engineering and Science, 23(5), 22-36, 1960. http://calteches.library.caltech.edu/1976/1/1960Botto m.pdf (31.10.2016)

[3] American Society of Precision Engineering. www.aspe.net (31.10.2016)

[4] Poprawe R. Lasertechnik für die Fertigung, Grundlagen Perspektiven und Beispiele für den innovation Ingenieur. Berlin-Heidelberg, Germany, Springer Verlag, 2005.

[5] Lunney JG, Jordan R. "Pulsed laser ablation of metals". Applied Surface Science, 127-129, 941-946, 1998.

[6] Trtica MS, Radak BB, Gakovic BM, Milanovic DS, Batani D, Desai T. "Surface modifications of Ti6Al4V by a picosecond Nd:YAG laser". Laser and Particle Beams, Cambridge University Press, 27, 85-90, 2009.

[7] Dahotre NB, Harimkar SP. Laser Fabrication and Machining of Materials. New York, USA, Springer Verlag, 2008. 
[8] Chaudhuri A, Hadjadj A, Guha C, Dutta TK. Numerical Simulations of Microscale Gas Flows: Continuum Approach. Editor: Strangio MA. Recent Advances in Technologies, 121-146, InTech, $2009 . \quad$ Available http://www.intechopen.com/books/recent-advances-intechnologies/numerical-simulations-of-microscale-gasflows-continuum-approach

[9] Kannatey-Asibu E. Principles of Laser Material Processing. Hoboken, New Jersey, USA; John Wiley \& Sons, Inc., 2009.

[10] Hirschfelder JO, Curtiss CF, Bird RB. Molecular Theory of Gases and Liquids. New York, USA, Wiley, 1954.

[11] Kelly R. "On the dual role of the Knudsen layer and unsteady, adiabatic expansion in pulse sputtering phenomena". Journal of Chemical Physics, 92(8), 5047-5056, 1990.

[12] Çelen S, Ozden H. "Laser-induced novel patterns: As smart strain actuators for new-age dental implant surfaces". Elsevier Applied Surface Science, 263, 579-585, 2012.

[13] Çelen S. "Pulsed laser-induced lotus leafs from the viewpoint of coalescence of sensors hypothesis". $18^{\text {th }}$ International Conference on Surface Modification of Materials by Ion Beams, Kuşadası, Turkey, 15-20 September 2013.

[14] Çelen S. "A novel strain energy density algorithm for laser induced micro-hollows". Elsevier Optics and Lasers in Engineering, 70, 45-50, 2015.

[15] Çelen S. "CPE: Novel method to shorten the lead time for laser micro-machining". Materials Testing, Carl Hanser Verlag GmbH \& Co. KG, Berlin, 57(6), 585-588, 2015.

[16] Çelen S. "On mechanism of explosive boiling in nanosecond regime". Applied Physics B:Lasers and Optics, Springer-Verlag Berlin Heidelberg, 6, 122-168, 2016.

[17] Afanas'ev YV, Krokhin ON. "Vaporization of matter exposed to laser emission". Soviet Physics Journal of Experimental and Theoretical Physics, 25(4), 639-645, 1967.

[18] Anisimov SI. "Vaporization of metal absorbing laser radiation". Soviet Physics Journal of Experimental and Theoretical Physics, 27(1), 182-183, 1968.

[19] Anisimov SI, Khokhlov VA. Instabilities in Laser-Matter Interaction. Boca Raton-FL, USA, CRC Press, 1995.

[20] Olstad RA, Olander DR. "Evaporation of solids by laser pulses. I. Iron". Journal of Applied Physics, 46(4), 1499-1508, 1975.

[21] Olstad RA, Olander DR. "Evaporation of solids by laser pulses. II. Zirconium hydride". Journal of Applied Physics, 46(4), 1509-1518, 1975.

[22] Andrews JG, Attey DR. "On the motion of an intensely heated evaporating boundary". Institute of Mathematics and its Applications (IMA) Journal of Applied Mathematics, 15(1), 59-72, 1975.

[23] Andrews JG, Attey DR. "Hydrodynamic limit to penetration of a material by a high-power beam". Journal of Physics D: Applied Physics, 9(15), 2181-2194, 1976.

[24] Allmen M. "Laser drilling velocity in metals". Journal of Applied Physics, 47, 5460-5463, 1976.

[25] Knight CJ. "Theoretical modeling of rapid surface vaporization with back pressure". American Institute of Aeronautics and Astronautics Journal, 17(5), 519-523, 1979.
[26] Chan CL, Mazumder JE. "One-dimensional steady-state model for damage by vaporization and liquid expulsion due to laser-material ablation". Journal of Applied Physics, 62(11), 4579-4586, 1987.

[27] Kelly R, Dreyfus RW. "Reconsidering the mechanisms of laser sputtering with Knudsen-layer formation taken into account". Nuclear Instruments and Methods in Physics Research Section B: Beam Interactions with Materials and Atoms, 32(1-4), 341-348, 1988.

[28] Kelly R, Dreyfus RW. "On the effect of Knudsen-layer formation on studies of vaporization, sputtering and desorption". Surface Science, 198(1-2), 263-276, 1988

[29] Singh RK, Narayan J. "Pulsed-laser evaporation technique for deposition of thin films: Physics and theoretical model". The American Physical Society Physical Review B, 41(13), 8843-8859, 1990.

[30] Aden M, Beyer E, Herziger G. "Laser-induced vaporization of metal as a Riemann problem". Journal of Physics D: Applied Physics, 23(6), 655-661, 1990.

[31] Aden M, Beyer E, Herziger G, Kunze H. "Laser-induced vaporization of a metal surface". Journal of Physics D: Applied Physics, 25(1), 57-65, 1992.

[32] Chen KR, Leboeuf JN, Wood RF, Geohegan DB, Donato JM, Liu CL, Puretzky AA. "Accelerated expansion of laserablated materials near a solid surface". The American Physical Society Physical Review Letters, 75(25), 47064709, 1995.

[33] Capewell DL, Goodwin DG. "Monte Carlo simulations of reactive pulsed laser deposition". Proceedings of SPIE 2403 Laser-Induced Thin Film Processing, 49-59, 1995.

[34] Peto G, Karacs A, Pastzi Z, Guczi L, Divinji T, Joob A. "Surface treatment of screw shaped titanium dental implants by high intensity laser pulses". Applied Surface Science, Proceeedings of the European Materials Research Society 2001-Symposium L "Photon-Induced Surface Processing", 186(1-4), 7-13, 2002.

[35] Voisey KT, Kudesia SS, Rodden WSO ,Hand DP, Jones JDC, Clyne TW. "Melt ejection during laser drilling of metals". Material Science and Engineering A , 356(1-2), 414-424, 2003.

[36] Atrique D, Alexiades V, Khanal H. "Hydrodynamic modelling of ns-laser ablation". Ninth MSU-UAB Conference on Differential Equations and Computational Simulations, Electronic Journal of Differential Equations, Conference, 20, 1-14, 2013. https://www.math.utk.edu/ vasili/va/descr/laser/79.D A-VA-HK.EJDE_2013-prepnt.pdf

[37] Phipps CR Jr., Dreyfus RW. The High Laser Irradiance Regime. Editors: Vertes A, Gijbels R, Adams F. Laser Ionization Mass Analysis, 369-431, New York, USA, John Wiley and Sons, 1993.

[38] Root RG. Modeling of post-breakdown phenomena. Editors: Radziemski LJ, Cremers DA. Laser-Induced Plasmas and Applications, 69-103, New York, USA, Marcel Dekker Inc., 1989.

[39] Bergel'son VI, Loseva TV, Nemchinov IV, Orlova TI. "Propagation of plane supersonic radiation waves". Soviet Journal of Plasma Physics, 1(6), 498, 1975. 
[40] McKay JA, Weiting TJ, French FW. "Pressure and Impulse Generation by Laser-Driven Air Plasmas at High Intensity and Short Pulse Duration". American Institute of Aeronautics and Astronautics (AIAA) Paper, 17th Fluid Dynamics, Plasma Dynamics, and Laser Conference, Snowmass, Colo.,USA, 84-1586, 25-27 June 1984

[41] Ding K, Ye L. Laser shock peening performance and process simulation. Woodhead Publishing and Maney Publishing, CRC Press, 2006.

\section{Nomenclature}

\begin{tabular}{cccc}
\hline Physical & Symbol & Value & Unit \\
Properties & & & \\
\hline Mass Density & $\rho$ & 4.54 & $\mathrm{~kg} / \mathrm{m}^{3}$ \\
Vaporization & $\mathrm{L}_{\mathrm{v}}$ & $8.893^{*} 10^{\wedge} 6$ & $\mathrm{~J} / \mathrm{kg}$ \\
Enthalpy & & $0.47^{*} 10^{\wedge}-26$ & $\mathrm{~kg}$ \\
Atomic Mass & $\mathrm{m}$ & 47.867 & $\mathrm{~g} / \mathrm{mol}$ \\
Molar Mass & $\mathrm{M}$ & $1420-1428$ & $\mathrm{MW} / \mathrm{cm}^{2}$ \\
Laser & $\mathrm{I}$ & 3562 & $\mathrm{~K}$ \\
Intensity & & & \\
Vaporization & $\mathrm{T}$ & $1.3865^{*} 10^{\wedge}-$ & $\mathrm{J} / \mathrm{K}$ \\
Temperature & & 23 & \\
Boltzmann & $\mathrm{B}_{\mathrm{t}}$ & 0.54 & $\mathrm{~kJ} / \mathrm{kg} . \mathrm{K}$ \\
Constant & & & \\
Specific Heat & $\mathrm{C}_{\mathrm{p}}$ & &
\end{tabular}

